\title{
Phosphate of iron, mangsanese and soda
}

\section{M.A. Damour}

To cite this article: M.A. Damour (1848) Phosphate of iron, mangsanese and soda, Philosophical Magazine Series 3, 32:212, 74-74, DOI: 10.1080/14786444808645924

To link to this article: http://dx.doi.org/10.1080/14786444808645924

曲 Published online: 30 Apr 2009.

Submit your article to this journal 준

Џ Article views: 2

Q View related articles $₫$ 


\title{
XII. Intelligence and Miscellaneous Articles.
}

\author{
PHOSPHATE OF IRON, MANGANESE AND SODA. \\ BY M. A. DAMOUR.
}

THIS mineral was recently found among the pegmatites of the environs of Chanteloub, near Limoges, by M. Mathieu, a mineral-dealer.

When viewed in mass, its colour is slove-brown; its fracture lamellar and shining; and in some places, which appear altered, it is chatoyant like diallage. It possesses three rectangular cleavages, which leads to the conclusion that the mineral crystallizes in right rectangular prisms. This mineral scratches fluor spar, and is scratched by a steel point; its density is $3 \cdot 468$. When heated by the blowpipe on platina, it melts into a non-magnetic globule. With fluxes it gives the reactions of manganese, and gives water when heated in the tube. Hydrochloric acid dissolves it readily, a little chlorine being evolved.

A qualitative analysis showed that the mineral is composed essentially of phosphoric acid, peroxide of iron, and oxide of manganese and soda, combined with a small quantity of water.

The mean of six analyses gave-

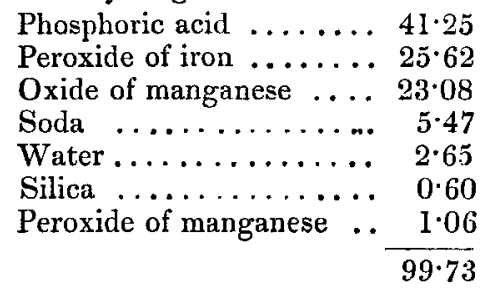

The physical characters and chemical composition of this mineral distinguish it from all previously known phosphates, and show that it should be classed as a distinct species.-Comptes Rendus, Novembre 1847 .

\section{ANALYSIS OF COLUMBITE FROM THE FNVIRONS OF LIMOGES, BY M. A. DAMOUR.}

This mineral species, which has hitherto been found in a few places only, has been met with in a quarry near Chanteloub. The specimen, below described, was confounded with specimens of wolfram and triplite, which M. Mathieu had collected. Its colour, hardness and great density, induced M. Damuur to believe that it contained columbic acid. It occurs in the form of nuclei imbedded in yellowish-white felspar. It is of a tarnished bluish-black colour on the surface; the fresh fracture is shining and glossy; its powder is black, approaching gray. It scratches glass, and its density is $7 \cdot 651$. It does not fuse by the blowpipe ; but when heated on charcoal with tartrate of potash, it yields globules of tin. Acids do not act upon it. Analysis gave- 